\title{
Zfp423/OAZ Mutation Reveals the Importance of Olf/EBF Transcription Activity in Olfactory Neuronal Maturation
}

\author{
Yang A. Roby, ${ }^{1}$ Michael A. Bushey, ${ }^{1}$ Li E. Cheng, ${ }^{1}$ Heather M. Kulaga, ${ }^{1}$ Se-Jin Lee, ${ }^{2}$ and Randall R. Reed ${ }^{1}$ \\ ${ }^{1}$ Center for Sensory Biology, ${ }^{2}$ Department of Molecular Biology and Genetics, Johns Hopkins University School of Medicine, Baltimore, Maryland 21205
}

Zfp423/OAZ, a multi-zinc finger protein, is proposed to participate in neuronal differentiation through interactions with the Olf/EBF (O/E) family of transcription factors and mediate extrinsic BMP signaling pathways. These activities are associated with distinct domains of the Olf/EBF-associated zinc finger (OAZ) protein. Sustained OAZ expression arrests olfactory sensory neurons (OSNs) at an immature state and alters olfactory receptor expression, but the mechanism remains elusive. We show here that constitutive expression of a C-terminal mutant $\mathrm{OAZ}(\mathrm{OAZ} \Delta \mathrm{C})$ in mice that selectively disrupts $\mathrm{OAZ}-\mathrm{O} / \mathrm{E}$ interaction while retaining other activities, exhibits apparently normal OSN differentiation. Additionally, interfering with potential BMP signaling pathways by inducible Follistatin expression in adult mice does not alter the neuronal lineage or differentiation status. Our results indicate that $0 / \mathrm{E}$-mediated processes are essential for the differentiation of OSNs and the establishment of a mature phenotype. BMP signaling pathways, if they are active in normal adult olfactory epithelium, may play a minor role in this tissue.

\section{Introduction}

The main olfactory epithelium (MOE) has evolved highly specialized sensory neurons for odorant detection. These neurons are replaced constantly and regenerate after acute injury (Graziadei and Graziadei, 1979; Verhaagen et al., 1990; Schwob et al., 1994; Schwob, 2002). The remarkable properties of these cells make the MOE an excellent system to investigate intrinsic and extrinsic contributions to neuronal development.

Olfactory sensory neuron (OSN) stem cells sequentially express several neuronal markers and subsequently developed into mature neurons. Expression of odorant transduction components and additional proteins characteristic of OSNs are hallmarks of terminal differentiation. The contribution of specific transcription factors to the mature phenotype has not been established.

The Olf/EBF (O/E) family of repeat helix-loop-helix transcriptional factors activates expression of genes associated with neuronal maturation and B-cell differentiation (Hagman et al., 1993; Wang and Reed, 1993; Wang et al., 1997). This family comprises four structurally similar $\mathrm{O} / \mathrm{E}$ proteins with overlapping MOE expression (Wang et al., 1997, 2004) that form homodimers and heterodimers

\footnotetext{
Received Dec. 13, 2011; revised June 15, 2012; accepted June 26, 2012.

Author contributions: Y.A.R., M.A.B., L.E.C., and R.R.R. designed research; Y.A.R., H.M.K., and R.R.R. performed research;S.-J.L. contributed unpublished reagents/analytic tools; Y.A.R. and R.R.R. analyzed data; Y.A.R. and R.R.R. wrote the paper.

This work was supported by NIH Grants DC008295 (R.R.R.) and HD35887/AR060636 (S.-J.L.). We thank Dr. P. Mombaerts for the OR-reporter, OMP-Tau-lacZ, and OMP-Cre mice; Dr. F. Margolis for the OMP antibody; the NIDDK National Hormone and Peptide Program for anti-Follistatin antibody; and the members of the Reed Laboratory for helpful discussions and review of this manuscript.

The authors declare no competing financial interests.

Correspondence should be addressed to Randall R. Reed, Center for Sensory Biology, Department of Molecular Biology and Genetics, Johns Hopkins University School of Medicine, 855 North Wolfe Street, Rangos Building 430, Baltimore, MD 21205. E-mail: rreed@jhmi.edu.

L. E. Cheng's present address: Department of Physiology, Howard Hughes Medical Institute, University of California, San Francisco, San Francisco, CA 94158.

DOI:10.1523/JNEUROSCI.6190-11.2012

Copyright $\odot 2012$ the authors $\quad 0270-6474 / 12 / 3213679-10 \$ 15.00 / 0$
}

and recognize consensus DNA regulatory sites adjacent to genes selectively expressed in mature OSNs (Wang and Reed, 1993). In contrast to B-cell development, the extensive genetic redundancy of O/E proteins in the MOE may account for the modest developmental defects in individual gene knock-outs (Wang et al., 1997). Discrepancies between the timing of $\mathrm{O} / \mathrm{E}$ protein expression and induction of putative O/E-regulated transcription suggested that complex regulation of the $\mathrm{O} / \mathrm{E}$ factor activity underlies the contribution of these factors in the terminal phenotype.

The Zfp423/OAZ protein, containing 30 Krüppel-like $\mathrm{C} 2 \mathrm{H} 2$ zinc fingers (Tsai and Reed, 1997a), encodes multiple functions including the modulation of $\mathrm{O} / \mathrm{E}$ activity. Olf/EBF-associated zinc finger (OAZ) disrupts $\mathrm{O} / \mathrm{E}$ dimer formation via zinc finger (ZF) 28-30, and thereby suppresses $\mathrm{O} / \mathrm{E}$ target gene activation in cell culture (Tsai and Reed, 1997a, 1998). Expression of OAZ in immature cells is consistent with a role in suppressing OSN maturation. Additionally, OAZ functions in BMP signaling pathways as a smad4 coactivator. This activity, mediated by ZF 9-19, is essential for BMPmediated expression during Xenopus neurogenesis (Hata et al., 2000). Mammalian BMP signaling is implicated in embryonic OSN neurogenesis (Wu et al., 2003; Gokoffski et al., 2011) where it may suppress OSNs differentiation. These dual OAZ activities potentially coordinate intrinsic transcriptional cascades and extrinsic signaling pathways into a common modulation cassette controlling OSN differentiation and maturation.

Persistent expression of OAZ in the OSN lineage leads to developmental arrest and defects in olfactory receptor (OR) selection (Cheng and Reed, 2007). These phenotypes could arise from either suppressing O/E-mediated gene expression or inhibiting BMPmediated neurogenesis. Here, we demonstrate that this OAZassociated phenotype arises from suppressing $\mathrm{O} / \mathrm{E}$ function. In contrast with the phenotype associated with persistent wild-type (wt) OAZ protein, sustained expression of OAZ protein selectively lacking $\mathrm{O} / \mathrm{E}$ interaction $(\mathrm{OAZ} \Delta \mathrm{C})$ exhibits largely normal gene ex- 
pression. In addition, we provide evidence that interfering with BMP signaling at an adult stage has only a modest impact on neurogenesis and the appearance of the MOE. Genetic manipulation of OAZ expression and its interaction domains provides evidence that highlights the role of $\mathrm{O} / \mathrm{E}$ factors in OSN neurogenesis.

\section{Materials and Methods}

Mouse lines. The $\mathrm{O} / \mathrm{E} 3^{\mathrm{OAZ} \Delta \mathrm{C}}$ knock-in targeting construct was generated through mutagenesis introducing a " $\mathrm{T}$ " insertion at 3877 in OAZ cDNA by QuikChange Site-Directed Mutagenesis (Stratagene). The OAZ $\Delta \mathrm{C}$ minigene is followed by IRES-3NLS-YFP-pA and LoxP-TK $(\Delta)$-NeoLoxP cassettes. This modified minigene was introduced into $\mathrm{O} / \mathrm{E} 3$ knock-out targeting vector (Wang et al., 2004) at a position 261 bp before $\mathrm{O} / \mathrm{E} 3$ translation start site. $\mathrm{O} / \mathrm{E} 3{ }^{\mathrm{OAZ}}$ and $\mathrm{O} / \mathrm{E} 3^{\mathrm{OAZ} \Delta \mathrm{C}}$ mice were created in a mixed 129 and C57BL10/J background and have been maintained in this mixed hybrid background for at least 10 generations. Additional reporter lines (OMP-Tau-lacZ, M72-Tau-lacZ, P2-Tau-lacZ, and OMPCre mice) were obtained from Dr. P. Mombaerts (Max Plank Institute for Biophysics, Frankfurt, Germany). Cyp2g1-rTTA mice were provided by Dr. A. Lane (Johns Hopkins University Baltimore, MD). Tet O-Follistatin mice were generated by pronuclear injection of an expression construct consisting of the Follistatin (FST) expression cassette (Lee, 2007) between the expression of tetracycline response element (TRE)-promoter and upstream of polyadenylation signals derived from SV40 (simian virus 40). This entire cassette was immediately cloned downstream of six tandem copies of a synthetic transcriptional termination cassette to prevent undesired expression from potential promoters. For FST induction, all mice were fed with grainbased doxycycline mouse diet ( $2 \mathrm{~g} / \mathrm{kg}$; Bio-Serv) for 1 month after weaning. Mice used in experiments were from either sex.

In situ hybridization, immunohistochemistry, and X-gal staining. Olfactory tissue dissected from mice of the same gender ( 1 month of age) was prepared for in situ hybridization (ISH) and immunohistochemistry (Lewcock and Reed, 2004). In situ hybridization (Wang et al., 2004) was performed using paraformaldehyde (PFA)-fixed sections with the following probes: OAZ (nucleotides 263-1614 of NM_033327), O/E3 (O/E3 3'-UTR), growthassociated protein 43 (GAP43) (nucleotides 147-806 of NM_030553), Follistatin (nucleotides 1-1034 of NM_013409), olfactory marker protein (OMP) (partial cDNA of NM_011010), BMP2 (nucleotides 521-1177 of NM_007553), BMP4 (nucleotides 438-1223 of NM_007554), and BMP6 (nucleotides 638-1095 of NM_007556). Images were captured with a Zeiss Axioplan microscope.

Immunohistochemistry was performed on PFA- or Bouin's solution (Sigma-Aldrich)-fixed sections. The primary antibodies were rabbit antiGFP (1:1000; Invitrogen), rabbit anti-adenylyl cyclase 3 (ACIII) (1:1000; Santa Cruz Biotechnology), goat anti-OMP (1:1000; gift from Dr. F. Margolis, University of Maryland, Baltimore, MD), mouse anti-GAP43 (1:500; Millipore), rabbit anti-hFollistatin (1:1000; NIDDK National Hormone and Peptide Program), mouse anti- $\beta$-actin (1:2000; Abcam), rat anti-BrdU (1:100; Abcam). OMP, GAP43, and Follistatin staining used antigen retrieval in citrate buffer. Sections were Bouin's fixed for OMP staining. Alexa 488 or Alexa 546-conjugated IgG or Fab secondary antibodies (1:1000; Invitrogen) were used to visualize staining. Images were captured with LSM510 confocal microscope.

$\mathrm{X}$-gal staining of whole-mount preparations and cryosections were performed on mouse (3 weeks of age; same gender) olfactory tissue (Mombaerts et al., 1996), and images were captured with a Leica MZ FLIII stereomicroscope or Zeiss Axioplan microscope.

Chromatin immunoprecipitation, RNA isolation, and real-time PCR. All the mice ( 2 months of age; same gender) were killed by $\mathrm{CO}_{2}$. For chromatin immunoprecipitation (ChIP) assays, the MOE from 1-month-old mice were dissected in $1 \times$ PBS and minced before cross-linking with 20 mм DSG (disuccinimidyl glutarate) (Thermo Fisher Scientific) for 45 min at room temperature followed by $1 \%$ formaldehyde (SigmaAldrich) for $15 \mathrm{~min}$ in $37^{\circ} \mathrm{C}$. The tissue was lysed and sonicated in $1 \mathrm{ml}$ of ChIP buffer (50 mm HEPES/NaOH, pH 7.5, 140 mm NaCl, 1\% Triton X-100, 0.1\% Na-deoxycholate, 0.1\% SDS, 1 mm PMSF, 1 mm EDTA, and a proteinase inhibitor mixture). The resulting lysates were divided and mixed with $4 \mu \mathrm{g}$ of mouse monoclonal anti-O/E antibody (Santa Cruz
Biotechnology; C-8) or a nonspecific IgG control (anti-NCAM antibody; Santa Cruz Biotechnology) before conjugation to protein A/G beads (Santa Cruz; sc-2003). After sequential washes according to instructions (ChIP Assay Kit; Millipore Corporation) and cross-link reversal followed by proteinase $\mathrm{K}$ digestion, the precipitated DNA was purified and eluted using PCR purification column (QIAGEN) for the Q-PCR analysis.

For Q-PCR analysis of gene expression, the olfactory tissue was homogenized and RNA was isolated with Trizol (Invitrogen) incubation at room temperature for $5 \mathrm{~min}$. A $0.2 \mathrm{vol}$ of chloroform was added, mixed, and centrifuged at $12,000 \times \mathrm{g}$ for $15 \mathrm{~min}$ at $4^{\circ} \mathrm{C}$. Supernatant was decanted and precipitated with ethanol, and the RNA was purified on RNeasy mini kit (QIAGEN) columns. One microgram of RNA was DNase treated and reverse transcribed into cDNA (Invitrogen) according to the first-strand cDNA synthesis protocol. Real-time PCR was performed using StepOnePlus PCR system (Applied Biosystems). Data are presented as mean $\pm \mathrm{SEM}$.

Primers used in this study were as follows: OE- 1 , forward, $5^{\prime}$-CC AACCTTCCTCAATGGCTCAG-3'; reverse, 5'-TGGCACAATGGCAT AGGGTG-3'; OE-3, forward, 5' -GGCAATGGGAACGGATTCAG-3'; reverse, 5' -ATCGGGGGAACAACAAGTCCTGTC-3'; GAP43, forward, 5' -CT GAGGAGGAGAAAGACGCTGTA-3'; reverse, $5^{\prime}$-ATCCTGTCGGGC ACTTTCC-3' ${ }^{\prime}$; OMP, forward, 5' -AGCCCGCTGTGACCTTAGG-3'; reverse, $5^{\prime}$-GATCAAGCCCCGCTGTCAT-3'; hFollistatin, forward, 5'-TTGCCTCCTGCTGCTGCTGC-3'; reverse, 5' -CTCCTTGCTCAGTTCG GTCTTG-3'; NeuroD1, forward, 5'-AACCTTTTAACAACAGGAAGTGGA A-3'; reverse, 5' -CTGAGGCTCGCCCATCAG-3'; Ngn 1, forward, 5' -CAAT ACAATGGCAAGGCTTAAAAA-3'; reverse, 5'-TCGGGATCCATA ATGCATGA-3'; Mash1, forward, 5'-TTTGGAAGCAGGATGGCAG CAG-3'; reverse, 5' -TTTCTGCCTCCCCATTTGA-3'; OAZ, forward, 5'-GCGATCGGTGAAAGTTGAAGA-3'; reverse, 5' -TGCTGCCACA GAGGAATCC-3'; YFP, forward, 5'-AGCAAAGACCCCAACGAG AA-3'; reverse, 5' -GGCGGCGGTCACGAA-3'; GAPDH, forward, 5' AATGGTGAAGGTCGGTGTGAAC-3'; reverse, 5' ${ }^{\prime}$-AATGGTGAAG GTCGGTGTGAAC-3'; OMP promoter, forward, 5' -GCATCTCTGT CTCCACCACTCA-3'; reverse, 5'-TGTATGTGGACAGATGGCAG AAC-3'; OcNC promoter, forward, 5'-AGGTGGGCTGCCTGGAA-3'; reverse, 5'-GCTCATGGCCACCTAACCA-3'; ACIII promoter, forward, 5'-CA CGTTTTCTTTTCAGCTTGGA-3'; reverse, 5'-CGGCTCTATCCCTGACTT CCT-3'; $\alpha$-actin promoter, forward, 5'-GACAGGCGGTCACACGGAC-3'; reverse, $5^{\prime}$-GTCTCCAGGTCACCCTCCC-3'.

Glutathione S-transferase-pull-down assay and Western blot. The glutathione $S$-transferase (GST)-pull-down assay was performed as described previously (Tsai and Reed, 1997a,b). GST, GST-RoazD86, and GSTRoazD86 $\Delta$ C fusion proteins were purified from cell lysates using glutathione Sepharose beads (GE Healthcare). GST fusion protein-bound glutathione-conjugated beads were incubated with $200 \mu \mathrm{g}$ of O/E-1 lysate overnight. Beads were washed six times $(500 \mathrm{~mm}$ Tris, $\mathrm{pH} 7.4,150$ $\mathrm{mm} \mathrm{NaCl}, 1 \% \mathrm{NP}-40,1 \%$ sodium deoxycholate) and two-thirds of the potential complexes were fractionated on a 10\% SDS-PAGE gel after sample buffer addition. Western blot analysis was performed using rabbit anti-O/E1 antibody (1:1000). GFP and $\beta$-actin were visualized from tissue homogenized in sample buffer and centrifuged at 13,000 rpm for $30 \mathrm{~min}$ at $4^{\circ} \mathrm{C}$. For each sample, 2-mercaptoethanol was added just before loading. Samples were gel fractionated and transferred to nitrocellulose membrane.

Luciferase assay. Each data point of $\mathrm{O} / \mathrm{E}$ responsive reporter assay represents triplicate transfections from two separate experiments. HEK293 cells were seeded in 12-well plates and transfected with FuGENE 6 (Roche) at $60-70 \%$ confluency. Cells were cotransfected with 100 ng of pGLPX10 O/E reporter along with $25 \mathrm{ng}$ of pRK5-O/E-1 and/or $250 \mathrm{ng}$ of pRK5-GSTRoazD86/ $\Delta C$, as appropriate. Transfections were adjusted to $500 \mathrm{ng}$ of total DNA with pRK5 empty expression vector. Luciferase activity was measured $24 \mathrm{~h}$ after transfection with Dual-Luciferase Assay Kit (Promega). The relative activity was expressed as values normalized to cotransfection samples with the reporter transfection alone control.

For BMP reporter assays, P19 cells in 12-well plates were transfected with 250 ng of reporter (BREx2-luc; obtained from Dr. P. Ten Dijke, The Netherlands Cancer Institute, Amsterdam, The Netherlands) alone or with $250 \mathrm{ng}$ of full-length OAZ/ $\triangle \mathrm{C}$ cDNAs. The cells were transfected at $60 \%$ confluence 

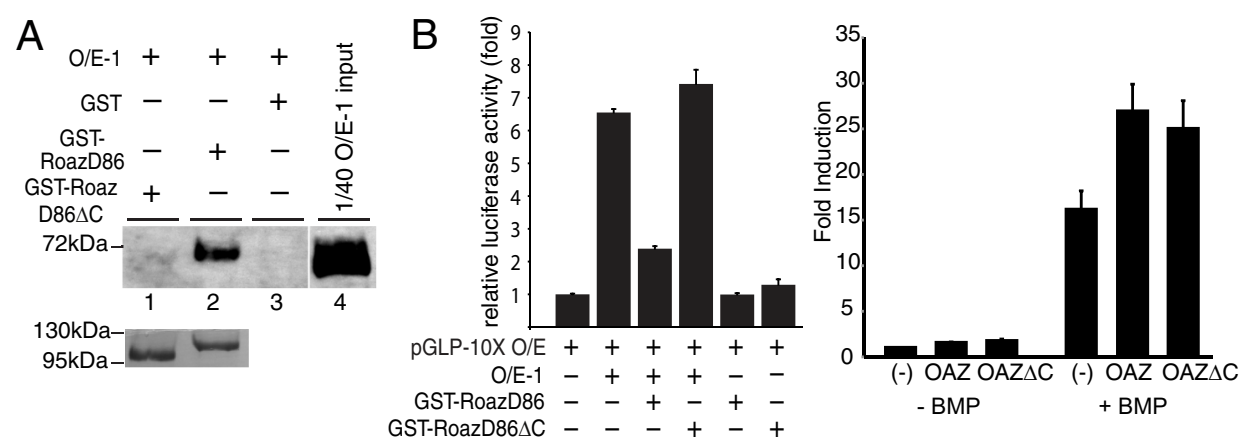

C
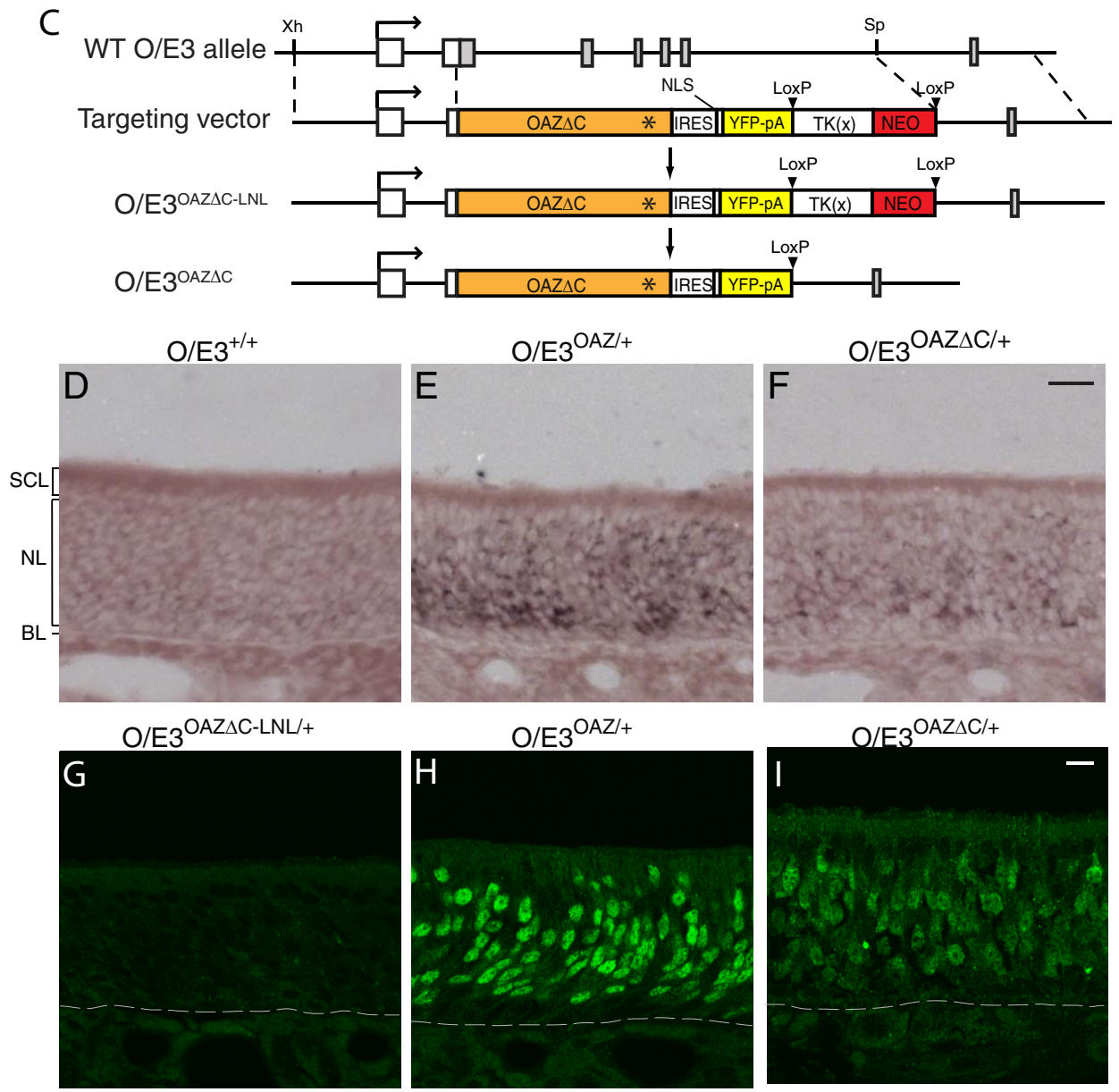

$J$
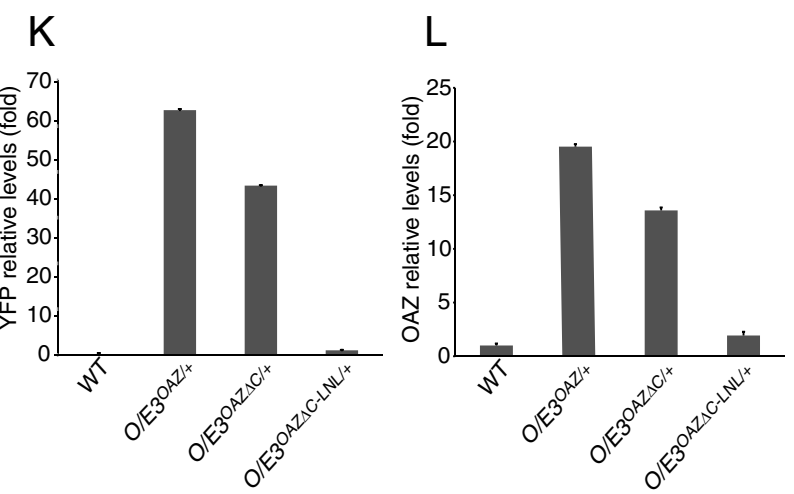

Figure 1. Generation of mice with OAZ protein with altered biochemical and transcriptional properties. $A, 0 A Z \Delta$ C abolishes $0 /$ Einteraction. GST-fusion proteins from HEK293 lysates were bound to glutathione beads and used to precipitate 0/E-1 protein from whole-cell lysates. Bound proteins were examined by Western blot with anti-0/E-1 antibody (top panel). Input corresponds to $1 / 40$ of $0 / E-1$ input lysate. Relative abundance and differential mobility of the GST-OAZ and GST-OAZ $\triangle$ ( proteins used in precipitation is shown (bottom panel). B, Left, 0/E-1 activates luciferase reporter in the presence of $\mathrm{OAZ} \triangle \mathrm{C}$. Luciferase reporter with $10 \mathrm{0} / \mathrm{E}$ binding sites adjacent to a minimal promoter (pGLP-10 $\mathrm{O}$ /E) was transfected alone or cotransfected with GST-fusion OAZ constructs in the presence or absence of 0/E-1. Relative luciferase activity was calculated by dividing absolute luciferase units for each transfection with that of reporter alone (Figure legend continues.) 
and cultured for $30 \mathrm{~h}$. Cells were transferred to low serum media (2\%), and BMP2 (1 nM; Invitrogen) was added for an additional $18 \mathrm{~h}$. Luciferase activity was measured by the same method as above. The relative luciferase activity is expressed as values normalized to reporter alone transfection in the absence of BMP2 induction.

BrdU labeling and cell counting. Mice (P24; same gender) were injected with $\mathrm{BrdU}(0.5 \mathrm{mg}$ per $10 \mathrm{~g}$ body weight, i.p.) and $2 \mathrm{~h}$ later killed with an overdose of Xylaket and transcardially perfused with PFA. Tissues were cut (18 $\mu \mathrm{m}$ coronal sections) and stained for BrdU, and cell counts were obtained following a published protocol (Cheng and Reed, 2007; Leung et al., 2007).

Statistics. The data are represented as mean \pm SEM. Two-way ANOVA test was used for cell counting in OR-positive cells.

\section{Results}

\section{Deletion of the OAZ C terminus abolishes $\mathrm{O} / \mathrm{E}$ binding but} retains $B M P$ activation

The OAZ protein domains mediating distinct interactions with associated partners can in principle be independently modified to investigate specific activities in vitro. Previously, the region responsible for O/E interaction was localized to ZF 28-30 through yeast two-hybrid assays and coimmunoprecipitation studies on a series of truncation mutants (Tsai and Reed, 1997a). We therefore introduced a single-nucleotide insertion between ZF 27 and 28 corresponding to amino acid 1208 of the OAZ protein. This mutation creates a termination codon and an altered reading frame for any read-through protein. This truncation, OAZ $\Delta$ C, was retested in the previously described biochemical interaction assays. OAZ and OAZ $\triangle \mathrm{C}$, expressed as purified GST-fusion partial protein (GST fused before ZF13), were added to O/Econtaining cell lysates and potential complexes isolated on glutathione beads (Fig. 1A). Western blot analysis using an anti$\mathrm{O} / \mathrm{E}$ antibody revealed a strong OAZ-O/E interaction when ZF $28-30$ is present (lane 2) but no detectable OAZ $\Delta \mathrm{C}-\mathrm{O} / \mathrm{E}$ association for the truncated mutant (lane 1). As expected, GST protein did not associate with the $\mathrm{O} / \mathrm{E}$ transcription factor (lane 3). These observations, consistent with those previously reported (Tsai and Reed, 1998), provide the biochemical framework for examining the importance of OAZ-O/E interactions/functions in vivo.

Homodimers and heterodimers of $\mathrm{O} / \mathrm{E}$ family members activate mature neuronal gene expression through interacting with their cognate binding sites (Wang and Reed, 1993). The suppression of $\mathrm{O} / \mathrm{E}$ dimer formation and elimination of the active tran-

\section{$\leftarrow$}

(Figure legend continued.) (mean \pm SEM of independent transfections; $n=6$ ). Right, $0 \mathrm{AZ}$ and $O A Z \Delta C$ significantly activate BMP response reporter upon BMP2 induction. Luciferase reporter with two BMP binding sites adjacent to a minimal promoter (BREX2-luc) was transfected alone or cotransfected with full-length $\mathrm{AAZ}$ or $\mathrm{OAZ} \triangle \mathrm{C}$ constructs in the presence or absence of BMP2 induction. Relative luciferase activity was calculated as above with reporter alone without BMP2 induction (mean \pm SEM of independent transfections; $n=5$ for each condition). $C$, Schematic targeting map for $0 / E{ }^{O A Z \Delta C}$ mice. The premature nonsense mutation in $0 A Z \Delta C$ is indicated as an asterisk. The OAZAC minigene, followed by IRES-3NLS-YFP-pA and LNL cassette, was inserted in the $5^{\prime}$-UTR of $0 / E 3$ and replaced exons $2-6$. The arrow indicates the $0 / E 3$ transcriptional start site. White box, $5^{\prime}$-UTR. Filled gray box, Coding sequences of 0/E3. D-F, In situ hybridization for OAZ mRNA in $0 / E 3^{\mathrm{OAZ} \Delta C /+}$ mice $(\boldsymbol{F}), 0 / \mathrm{E}^{\mathrm{OAZ} /+}(\boldsymbol{E})$, and wild type (D). Age, P30. Scale bar: $\mathbf{D}-\mathbf{I}, 10 \mu \mathrm{m}$. G-J, YFP reporter expression assessed with GFP antibody revealed in $0 / \mathrm{E}^{\mathrm{OAZ} /+}(\boldsymbol{H}, \boldsymbol{J})$ and $0 / \mathrm{E} 3^{\mathrm{OAZ} \Delta \mathrm{C} /+}$ mice $(I, J)$, but not in $0 / \mathrm{E} 3^{\mathrm{OAZ} \Delta \mathrm{C}-\mathrm{LNL} /+}$ or wt mice $(\mathbf{G}, \boldsymbol{J})$. Immunostaining was performed in cryosections. Western blot analysis was performed using tissue homogenates. $\beta$-Actin was used as a loading control. Age, P30. $K-L$, YFP and OAZ/OAZ $\triangle C$ expression is significantly higher in targeted mice $\left(0 / \mathrm{E}^{\mathrm{OAZ} \Delta \mathrm{C} /+}\right.$ and $0 / E 3^{\mathrm{OAZ} /+}$ ) than in controls (0/E3 ${ }^{\mathrm{OAZ} \Delta \mathrm{C}-\mathrm{LNL} /+}$ or wt mice) by Q-PCR. mRNA levels of YFP and $O A Z$ were determined by comparing with normalized $\mathrm{Ct}$ of $0 / \mathrm{E}^{\mathrm{OAZ} \Delta \mathrm{C}-\mathrm{LNL} /+}$ and wild-type mice, respectively. $n=3$ for each genotype. Error bars indicate SEM. Age, P24. BL, Basal lamina; $\mathrm{NL}$, neuronal layer; SCL, sustentacular cell layer. The dashed line marks basal lamina. scription factor complexes, a function attributed to OAZ, should result in abolishment of the transcription activation. In contrast, $\mathrm{OAZ}$ protein that lacks the $\mathrm{O} / \mathrm{E}$ interaction domain would be incapable of suppressing $\mathrm{O} / \mathrm{E}$-mediated transcription. We measured $\mathrm{O} / \mathrm{E}-$ dependent transactivation in transient cotransfections with plasmids containing $\mathrm{O} / \mathrm{E}-1, \mathrm{OAZ}$, or OAZ $\Delta \mathrm{C}$. The reporter plasmid consisted of 10 concatamerized $\mathrm{O} / \mathrm{E}$ binding sites adjacent to a minimal promoter driving luciferase (Fig. 1B). Significant increase in reporter activity was observed when O/E was present (activation, $6.55 \pm 0.11$-fold; $n=6$; Fig. $1 B$ ). This activation was suppressed in the presence of interacting protein OAZ (activation, $2.39 \pm 0.08$-fold; $n=6$; Fig. $1 B$ ), suggesting that $\mathrm{OAZ}$ disrupted the active $\mathrm{O} / \mathrm{E}$ complexes and prevented their binding to DNA (Tsai and Reed, 1997a). In contrast, OAZAC failed to suppress $\mathrm{O} / \mathrm{E}$-mediated transcriptional activation (activation, $7.42 \pm 0.43$-fold; $n=6$; Fig. $1 B$, left). These results indicate that target sequences can be activated by $\mathrm{O} / \mathrm{E}$ in the presence of OAZ $\triangle \mathrm{C}$ mutant, but not wild-type OAZ. Introduction of OAZ or OAZ $\Delta \mathrm{C}$ in the absence of $\mathrm{O} / \mathrm{E}$ factor had no significant effect on basal activity of the reporter (Fig. $1 B$, left).

To demonstrate that OAZAC protein is properly folded and functional, we examined the well characterized BMP signaling activity ascribed to the ZFs that are present in both the OAZ and OAZ $\Delta$ C protein (Hata et al., 2000). Utilizing a BMP response reporter with two BMP response elements and a luciferase reporter (BREx2-luc), we observe significant enhancement of reporter activity for OAZ and OAZ $\triangle \mathrm{C}$ cotransfected cells over the levels observed with BMP2 induction alone (Fig. $1 B$, right). These data suggested that $\mathrm{C}$-terminal OAZ $\Delta \mathrm{C}$ is properly folded and retains its remaining bioactivities.

Together, these data suggest that elimination of ZF $28-30$ in OAZ selectively disrupts one aspect of normal OAZ activity, namely the suppression of $\mathrm{O} / \mathrm{E}$-mediated transcription, but retains its ability to stimulate BMP-responsive promoters. Using this mutant, it should be possible to dissect the importance of the $\mathrm{O} / \mathrm{E}$ family members in olfactory differentiation in vivo.

\section{Gain of function: constitutive expression of OAZAC throughout OSN differentiation}

The demonstration that the C-terminal zinc fingers of OAZ participate in modulation of $\mathrm{O} / \mathrm{E}$ activity provides an opportunity to selectively investigate this role independent of the other pathways, including BMP signaling, ascribed to OAZ. We therefore generated a mouse line carrying a gain-of-function construct in which the OAZAC mutant protein is persistently expressed in the OSN lineage of olfactory epithelium. To compare and contrast the activities associated with full-length $\mathrm{OAZ}$ and $\mathrm{OAZ} \Delta \mathrm{C}$, this mouse line used the same strategy as the previous $\mathrm{O} / \mathrm{E} 3^{\mathrm{OAZ}}$ mouse (Cheng and Reed, 2007) (Fig. 1C). The resulting mouse differs in only a single nucleotide (3877_3878insT corresponding to amino acid Q1208Ter). As a result, the OAZ protein is truncated just before ZF 28. In each case, the OAZ sequences are followed by an IRES-driven nuclear YFP (nYFP) reporter and a LoxP-flanked Neo cassette (LNL). The construct was inserted by homologous recombination at the $\mathrm{O} / \mathrm{E} 3$ locus to direct persistent expression in $\mathrm{O} / \mathrm{E}$-expressing cells. In summary, these two mouse lines $\left(\mathrm{O} / \mathrm{E} 3^{\mathrm{OAZ}}\right.$ and $\left.\mathrm{O} / \mathrm{E} 3^{\mathrm{OAZ} \Delta \mathrm{C}}\right)$ provide an essentially matched gene-targeting setting to explore the specific importance of $\mathrm{O} / \mathrm{E}$ transcription and its modulation by OAZ.

The expression of genes introduced at the $\mathrm{O} / \mathrm{E} 3$ locus, including OAZ/nYFP, is dependent on the Cre-mediated removal of the LNL cassette (Fig. 1C) (Cheng and Reed, 2007) and presumably derives from the Neo cassette blocking a downstream enhancer. Here, we 


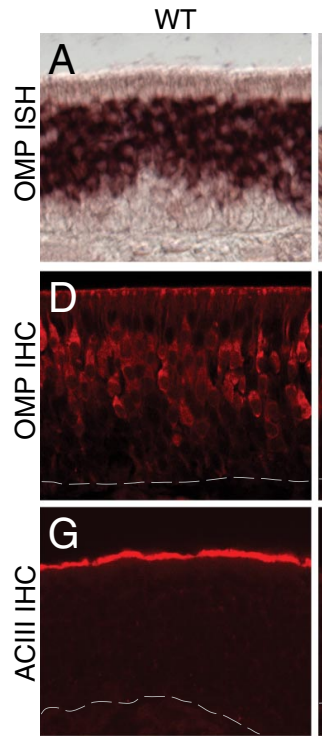

S

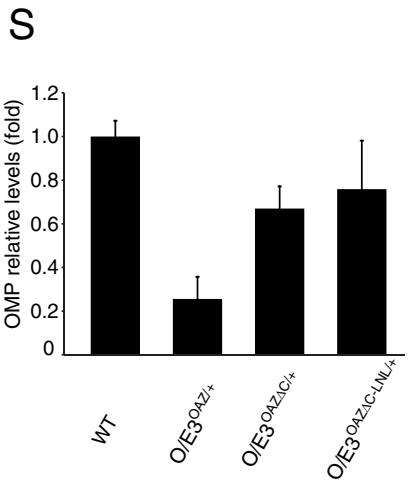

$\mathrm{O} / \mathrm{E}^{\mathrm{OAZ} /+}$
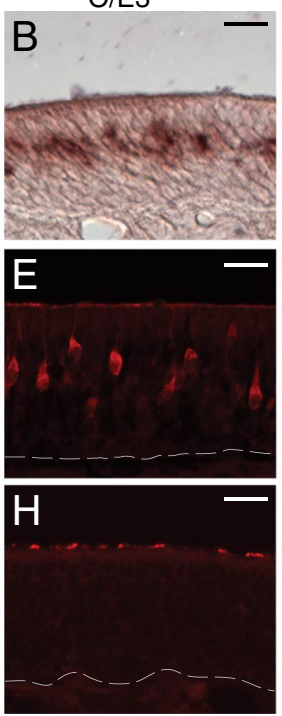

T

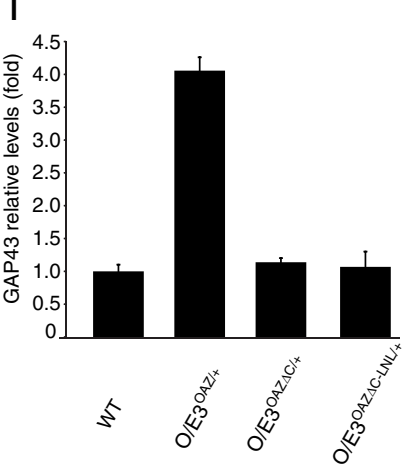

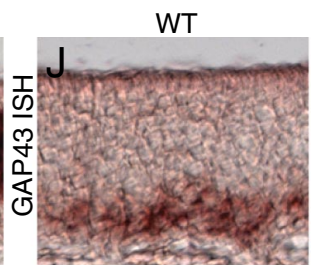
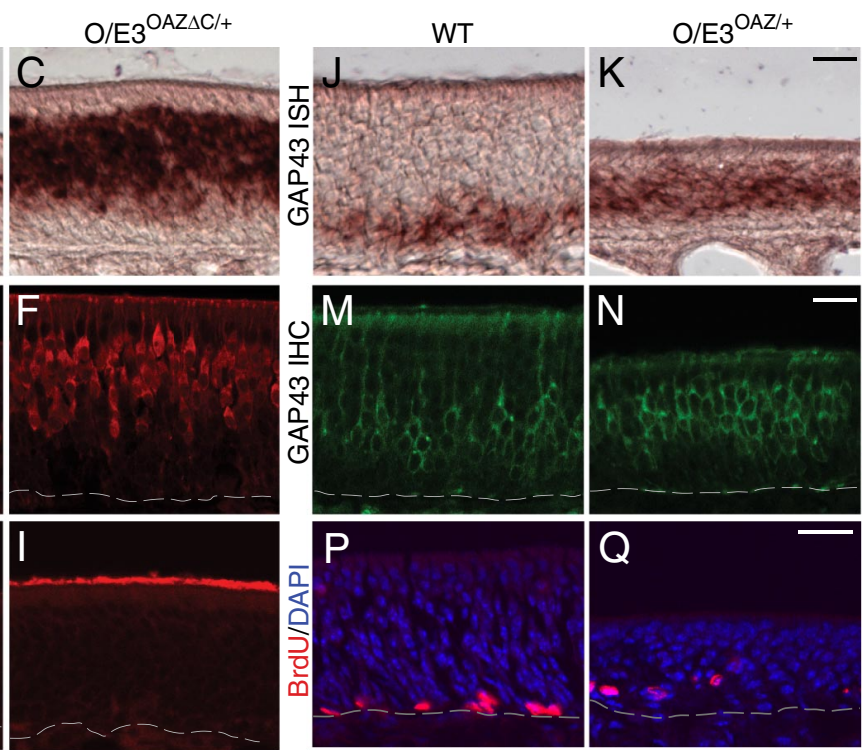

U

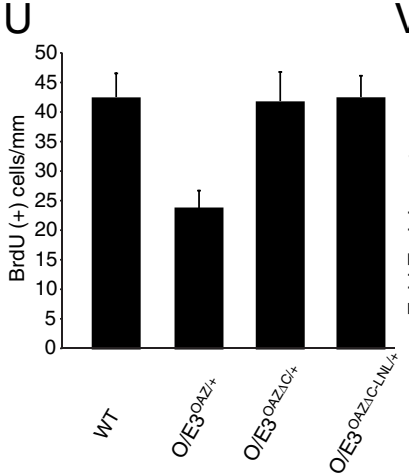

V

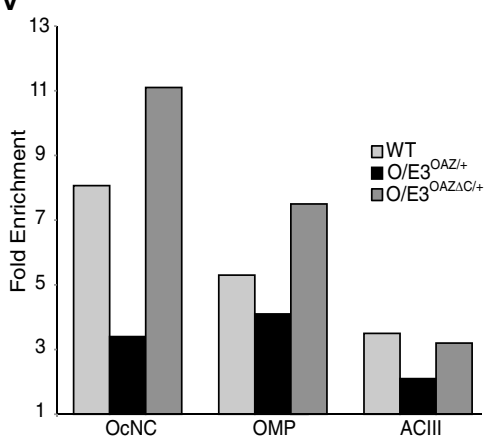

Figure 2. Sustained $0 \mathrm{AZ} \Delta$ C expression is compatible with $0 \mathrm{SN}$ maturation. $A-I, 0 \mathrm{MP}$ in situ hybridization and immunostaining (ACIII and $0 \mathrm{MP}$ ) in MOE reveals abundant and similar expression pattern in $0 / E 3^{\mathrm{OAZAC} /+}(\boldsymbol{C}, \boldsymbol{F}, \boldsymbol{I})$ and wild-type $(\boldsymbol{A}, \boldsymbol{D}, \boldsymbol{G})$, compared with few and scattered cells in $0 / \mathrm{E} 3{ }^{\mathrm{OAZ} /+}$ mice $(\boldsymbol{B}, \boldsymbol{E}, \boldsymbol{H}) . \boldsymbol{J}-\mathbf{0}, \mathrm{GAP43}$ in situ hybridization and staining revealed that immature 0 SN sare confined to basal

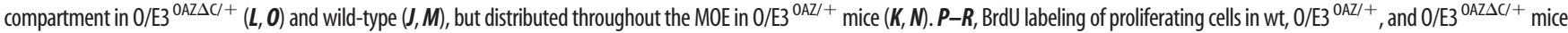
(quantified in $\boldsymbol{U}$ ). Scale bar, $20 \mu \mathrm{m}$. Age, P20.S, Q-PCR quantification of OMP expression showed comparable levels in $0 / \mathrm{E}{ }^{\mathrm{OAZ} \Delta \mathrm{C} /+}, 0 / \mathrm{E} 3^{\mathrm{OAZ} \Delta \mathrm{C}-\mathrm{LNL} /+}$, and wt mice, and a significant reduction in $0 / \mathrm{E} 3{ }^{\mathrm{OAZ} /+}$ mice. Error bars indicate SEM. $n=3$ for each genotype. $T$, Quantification of GAP43 expression by Q-PCR showed a comparable level in 0/E3 ${ }^{\text {OAZ } \Delta C /+}$, 0/E3 ${ }^{\text {OAZ } \Delta C-L N L /+}$, and wt mice and significant elevation in $0 / \mathrm{E} 3^{\mathrm{OAZ} /+}$ mice. $n=3$ for each genotype. $\boldsymbol{U}$, Quantification of BrdU-positive OSNs in MOE showed comparable number of proliferating cells in 0/E3 ${ }^{0 \mathrm{AZ} \Delta \mathrm{C} /+}$, $0 / \mathrm{E} 3^{\mathrm{OAZ} \Delta \mathrm{C}-\mathrm{LNL} /+}$, and wt mice and half-fold reduction in $0 / E 3^{\mathrm{OAZ} /+}$ mice. Error bars indicate SEM. $n=3$ mice for each genotype. Mice age is P20 for staining/in situ hybridization and P24 for Q-PCR. The dashed line marks basal lamina. $\boldsymbol{V}, 0 /$ E target gene enrichment by ChIP-Q-PCR. Both WT and 0/E3 ${ }^{0 A Z \Delta C /+}$ mice display a similar enrichment for $0 \mathrm{CNC}$, OMP, and ACIII promoter gene sequences. This contrasts with the lower enrichment in $0 / \mathrm{E}^{\mathrm{OAZ} /+}$-derived tissue. Fold enrichment is calculated from the ratio of Ct values for the $0 / \mathrm{E}$ target promoters and the $\alpha$-actin promotor control relative to the $\mathrm{Ct}$ values for the input DNA. The resulting values were normalized for enrichment of the respective sequences with a nonspecific lgG monoclonal (NCAM). Age, P30.

confirmed the above mechanism applies to $\mathrm{O} / \mathrm{E} 3^{\mathrm{OAZ} \Delta \mathrm{C}}$ mice. Specifically, we examined OAZ and OAZ $\Delta \mathrm{C}$ message expression by ISH (Fig. 1D-F). Only in "Neo-out" $\mathrm{O} / \mathrm{E} 3^{\mathrm{OAZ} /+}$ or $\mathrm{O} / \mathrm{E} 3^{\mathrm{OAZ} \Delta \mathrm{C} /+}$ mice were OAZ-containing transcripts readily detected in the epithelium (Fig. 1E,F). Endogenous OAZ message was barely detectable in "LNL" mice (data not shown) and wt (Fig. 1D), consistent with previous data (Tsai and Reed, 1997a). The message abundance was further quantified by Q-PCR analysis of OAZ transcripts (Fig. $1 L$ ), in which the Neo-out mice exhibited a 13- to 19-fold elevation in message compared with either wt or LNL mice. The fact that both wt and OAZ $\Delta$ C LNL mice exhibited similar levels in OAZ-containing transcripts indicated that the Neo cassette effectively blocked transcription of the locus in the absence of recombination and only the endogenous message was detected.

The YFP reporter protein was readily detectable and expressed at similar elevated levels compared with LNL or wt mice by immunofluorescence (Fig. 1G-I) and Western blot analysis (Fig. $1 J$ ). Likewise, the relative expression quantification revealed a $40-$ to 60 -fold increase in YFP message in Neo-out compared with
LNL/wt mice (Fig. $1 K$ ). Together, these observations provide evidence that the expression of OAZ $\Delta \mathrm{C}$ and associated YFP reporter can be effectively controlled by Neo cassette excision. These experiments also provide an additional control on the direct effects of OAZ $\Delta \mathrm{C}$ expression in contrast to other potential consequences of $\mathrm{O} / \mathrm{E} 3$ locus genetic modifications.

There is a modest reduction in OAZ $\Delta \mathrm{C}$ message and the associated YFP reporter protein compared with the $\mathrm{O} / \mathrm{E} 3{ }^{\mathrm{OAZ}}$ mice (Fig. $1 E, F ; H, I ; J--L)$, even though these two strains differ by a single nucleotide. This could arise because the two strains of mice have different populations of cells residing in the MOE (Fig. 2). Additionally, the activity of the $\mathrm{O} / \mathrm{E} 3$ promoter may vary in cells at different points in the differentiation pathway. The expression of O/E3 by ISH was similar in signal strength and expression pattern in $\mathrm{O} / \mathrm{E} 3{ }^{\mathrm{OAZ}}$ and $\mathrm{O} / \mathrm{E} 3^{\mathrm{OAZ} \triangle \mathrm{C}}$ mice, and slightly less abundant than wt mice with two functional O/E3 loci. Subsequent Q-PCR experiments for $\mathrm{O} / \mathrm{E}-3$ and $\mathrm{O} / \mathrm{E}-1$ were performed $(\mathrm{O} / \mathrm{E}-3$ in wt mice was 1.0 , while levels in $\mathrm{O} / \mathrm{E}^{\mathrm{OAZ} /+}$ and $\mathrm{O} / \mathrm{E} 3^{\mathrm{OAZ} \Delta \mathrm{C} /+}$ mice were 0.71 and 0.65 , respectively; O/E-1 in wt mice was 1.0 relative to levels of 1.07 and 
1.15 for $\mathrm{O} / \mathrm{E} 3^{\mathrm{OAZ} /+}$ and $\mathrm{O} / \mathrm{E} 3^{\mathrm{OAZ} \Delta \mathrm{C} /+}$ mice; $n=3$ for each genotype). Therefore, $\mathrm{O} / \mathrm{E} 3$ promoter activities were largely the same despite an altered differentiation status in $\mathrm{O} / \mathrm{E} 3^{\mathrm{OAZ} \Delta \mathrm{C}}$ mice. An alternative possibility is that premature translation of the OAZ open reading frame decreases the efficiency of ribosomes reinitiating at the downstream IRES site and modestly destabilizes the bicistronic message. Nevertheless, despite this modest message reduction, the OAZcontaining and reporter message levels in expressed strains (Neo-out $\mathrm{O} / \mathrm{E} 3^{\mathrm{OAZ}}$ and $\mathrm{O} / \mathrm{E} 3^{\mathrm{OAZAC}}$ mice) showed robust and comparable expression that contrasted with the lower levels in the parental lines (wt and LNL mice).

\section{Normal OSN maturation is observed in constitutively expressed OAZDC mice}

The persistent expression of OAZ protein during OSN differentiation prevents neuronal maturation (Cheng and Reed, 2007), although the specific contribution of $\mathrm{O} / \mathrm{E}$ interaction could not be assessed in this model. A similar persistent expression of the OAZ $\Delta C$ protein can illuminate the importance of O/E transcription in OSN maturation since persistent $\mathrm{OAZ} \Delta \mathrm{C}$ expression would retain most of the full-length protein but specifically lack the ability to perturb $\mathrm{O} / \mathrm{E}$ dimerization and subsequent transcription.

We examined several neuronal markers at distinct stages to characterize the consequences of OAZ/OAZ $\Delta \mathrm{C}$ expression by ISH and immunofluorescence. They are mature neuronal markers, OMP and ACIII, and the immature neuronal marker, GAP43. In $\mathrm{O} / \mathrm{E} 3^{\mathrm{OAZ} /+}$ mice, the $\mathrm{MOE}$ was largely depleted of $\mathrm{OMP}^{+}$cells (Fig. $2 B, E)$ indicative of neuronal differentiation arrest and the sparse $\mathrm{OMP}^{+}$cells likely represent "escapers" (Cheng and Reed, 2007). In contrast, the upper two-thirds of the epithelium was composed of $\mathrm{OMP}^{+}$mature OSNs in $\mathrm{O} / \mathrm{E} 3^{\mathrm{OAZ} \Delta \mathrm{C} /+}$ mice similar to wt littermates (Fig. $2 A, C, D, F)$. Likewise, ACIII, a mature neuronal signal component, showed discontinuous weak signal in the cilia layer of $\mathrm{O} / \mathrm{E}^{\mathrm{OAZ} /+}$ mice, while a continuous, uniform, intense layer was present in $\mathrm{O} / \mathrm{E} 3{ }^{\mathrm{OAZ} \Delta \mathrm{C} /+}$ and wt mice (Fig. $2 G-I$ ). These phenotypes provide the strong evidence that $\mathrm{O} / \mathrm{E}$ activity is critical to the maturation of OSNs. The expression pattern of GAP43, an immature neuronal marker, provides additional, complementary evidence for the importance of the $\mathrm{O} / \mathrm{E}$ transcription pathway. The accumulated $\mathrm{GAP}_{4} 3^{+}$cells in the MOE of O/E3 ${ }^{\mathrm{OAZ} /+}$ mice was reversed in $\mathrm{O} / \mathrm{E} 3^{\mathrm{OAZ} \Delta \mathrm{C} /+}$ mice, in which $\mathrm{GAP} 43^{+}$cells were restricted to the basal MOE compartment and resembled the pattern in wt mice (Fig. $2 J, L, M, O)$. Quantitative measurement of OMP and GAP43 mRNA further supported these observations. In $\mathrm{O} / \mathrm{E} 3^{\mathrm{OAZ} \Delta \mathrm{C} /+}$ mice, OMP mRNA levels were similar to wt and were dramatically reduced (fivefold) in $\mathrm{O} / \mathrm{E}^{\mathrm{OAZ} /+}$ mice (Fig. $2 S ; n=3$ for each genotype). The GAP43 mRNA level was comparable in $\mathrm{O} / \mathrm{E} 3^{\mathrm{OAZ} \Delta \mathrm{C} /+}$ mice and wt mice and contrasted with fourfold elevation detected in $\mathrm{O} / \mathrm{E} 3{ }^{\mathrm{OAZ} /+}$ animals (Fig. 2T; $n=3$ for each genotype). In parallel, we examined whether maintained OAZ/OAZ $\Delta \mathrm{C}$ expression alters proliferation of progenitors that renew the OSNs. BrdU ${ }^{+}$cell number were similar in $\mathrm{O} / \mathrm{E} 3^{\mathrm{OAZ} \Delta \mathrm{C} /+}$ and wt mice, but were decreased in $\mathrm{O} / \mathrm{E} 3^{\mathrm{OAZ} /+}$ mice (Fig. $2 U$ ). The proliferation observed in $\mathrm{O} / \mathrm{E} 3^{\mathrm{OAZ} \Delta \mathrm{C} /+}$ mice presumably reflects normal neuronal differentiation and maturation and suggests that the decreased level observed in the O/E3 ${ }^{\mathrm{OAZ} /+}$ mice is a consequence of changes in the mature population rather than hyperproliferation mediated directly by other functions of the OAZ protein.

The biochemical characterization of partially purified OAZ/ $\mathrm{OAZ} \Delta \mathrm{C}$ and $\mathrm{O} / \mathrm{E}$ protein interaction (Fig. $1 A$ ) and expression studies (Fig. $1 B$ ) suggests that the different phenotypes observed in the $\mathrm{OAZ}$ and $\mathrm{OAZ} \triangle \mathrm{C}$ mice derive their effects on $\mathrm{O} / \mathrm{E}$ protein function. In the OAZ mouse, the full-length protein can suppress functional
$\mathrm{O} / \mathrm{E}$ dimer binding to target genes in OSNs and their precursors, while in $\mathrm{OAZ} \Delta \mathrm{C}$ mice the $\mathrm{OAZ} \Delta \mathrm{C}$ protein does not interfere with $\mathrm{O} / \mathrm{E}-\mathrm{mediated}$ DNA binding and transcription activation. To directly examine $\mathrm{O} / \mathrm{E}$ binding to target gene sequences in vivo, we performed ChIP with an $\mathrm{O} / \mathrm{E}$ antibody (Fig. $2 \mathrm{~V}$ ). In wild-type tissue, sequences in proximity to the $\mathrm{O} / \mathrm{E}$ binding sites in the OcNC, OMP, and ACIII promoters were enriched 3.5- to 8-fold over that observed for a non-O/E-regulated promoter ( $\alpha$-actin) when precipitated with the monoclonal $\mathrm{O} / \mathrm{E}$ antibody. A nonspecific monoclonal IgG (NCAM) was used as a normalization control. The relative enrichment for each promoter region was markedly reduced in an O/E3OAZ knock-in tissue, consistent with a reduction in the ability to the $\mathrm{O} / \mathrm{E}$ protein to bind these targets in the presence of persistent $\mathrm{OAZ}$ protein. Finally, the relative enrichment of $\mathrm{O} / \mathrm{E}$ target gene sequences in OAZ $\Delta \mathrm{C}$ tissue were similar to wt as would be predicted if the OAZ $\Delta$ C protein was unable to disrupt $\mathrm{O} / \mathrm{E}$ function.

In summary, the ability of OAZ $\Delta \mathrm{C}$ to execute the normal neuronal differentiation program contrasts with the phenotypes of $\mathrm{O} / \mathrm{E} 3^{\mathrm{OAZ} /+}$ mice and specifically implicates $\mathrm{O} / \mathrm{E}$ transcription activity in OSN maturation.

\section{The O/E-mediated transcription pathway defines the phenotype in $\mathrm{O} / \mathrm{E} 3^{\mathrm{OAZAC}}$ mice}

The induction of OAZ expression in mature OSNs is sufficient to reactivate expression of immature neuronal markers (Cheng and Reed, 2007). The reactivated immature cells could arise from arrested $\mathrm{O} / \mathrm{E}$ function, or from the contributions of OAZ protein to other pathways including BMP signaling. The modified OAZ $\Delta \mathrm{C}$ permits normal $\mathrm{O} / \mathrm{E}$ function while simultaneously contributing to additional OAZ-mediated pathways retained in the mature cells. We crossed $\mathrm{O} / \mathrm{E} 3^{\mathrm{OAZ} \Delta \mathrm{C}-\mathrm{LNL} /+}$ and $\mathrm{O} / \mathrm{E} 3^{\mathrm{OAZ}-\mathrm{LNL} /+}$ mice with $\mathrm{OMP}^{\mathrm{Cre} / \mathrm{Cre}}$ mice to excise the Neo cassette specifically in mature OSNs and activate expression of the introduced OAZ alleles (Fig. 3J-L). Both ISH and immunohistochemistry revealed that introduction of wt $\mathrm{OAZ}$ produced ectopic $\mathrm{GAP} 43^{+}$immature cells and reduced $\mathrm{OMP}^{+}$cells in the apical MOE (Fig. $3 B, E, H$ ). These data contrasted with OAZ $\Delta \mathrm{C}$ mice that exhibited abundant $\mathrm{OMP}^{+}$ cells and no immature neurons in the apical MOE (Fig. 3C,F,I) similar to $\mathrm{OMP}^{\mathrm{Cre} /+}$ littermates in which neurons mature normally (Fig. $3 A, D, G$ ). These results suggest that the activity of $\mathrm{O} / \mathrm{E}$ factors, rather than BMP or other signaling pathways, dominate and define the mature fate when OAZ $\Delta \mathrm{C}$ is introduced OSNs. BMP signals could, however, contribute to cell phenotype but are unable to overcome the dominant differentiation drive mediated by $\mathrm{O} / \mathrm{E}$ factors.

\section{Minor defects in axonal projection and OR expression patterns in $\mathrm{O} / \mathrm{E} 3^{\mathrm{OAZ} \Delta \mathrm{C}}$ mice}

We next determined whether glomeruli targeting in olfactory bulb $(\mathrm{OB})$ and $\mathrm{OR}$ choice or expression were altered in $\mathrm{O} / \mathrm{E} 3^{\mathrm{OAZ} \Delta \mathrm{C}}$ mice. Three homozygous reporter mouse lines-OMP ${ }^{\text {Tau-LacZ/Tau-LacZ, }}$ M72 ${ }^{\text {Tau-LacZ/Tau-LacZ }}$, and P2 ${ }^{\text {Tau-LacZ/Tau-LacZ }}$ were crossed with $\mathrm{O} / \mathrm{E} 3^{\mathrm{OAZ} \Delta \mathrm{C} /+}$ mice for this examination. We detected no difference in axonal targeting, visualized in $\mathrm{OMP}^{\text {Tau-LacZ/+ }} ; \mathrm{O} / \mathrm{E} 3^{\mathrm{OAZ} \Delta \mathrm{C} /+}$ mice (Fig. 4A,B). Coronal sections confirmed the largely normal OB glomerular layer and $\mathrm{OMP}^{+}$cells in MOE. This observation contrasted with $\mathrm{O} / \mathrm{E} 3^{\mathrm{OAZ}}$ mice, in which dorsal $\mathrm{OBs}$ were devoid of axons and few $\mathrm{OMP}^{+}$neurons were present in the MOE (Cheng and Reed, 2007). To further analyze the axonal projection and OR choice, M72 (dorsal-projecting) and P2 (ventral-projecting) were examined. In dorsal views of $\mathrm{M} 72^{\text {Tau-LacZ/+ }} ; \mathrm{O} / \mathrm{E} 3^{\mathrm{OAZ} \Delta \mathrm{C} /+}$ mice, axons follow a similar route but some innervate aberrant extra glomeruli (Fig. $4 C-F ; n=7)$. The precision of axonal projection in $\mathrm{P}_{2}^{\text {Tau-LacZ/+}} ; \mathrm{O} /$ $\mathrm{E} 3^{\mathrm{OAZ} \Delta \mathrm{C} /+}$ reporter mice was more difficult to assess since they con- 

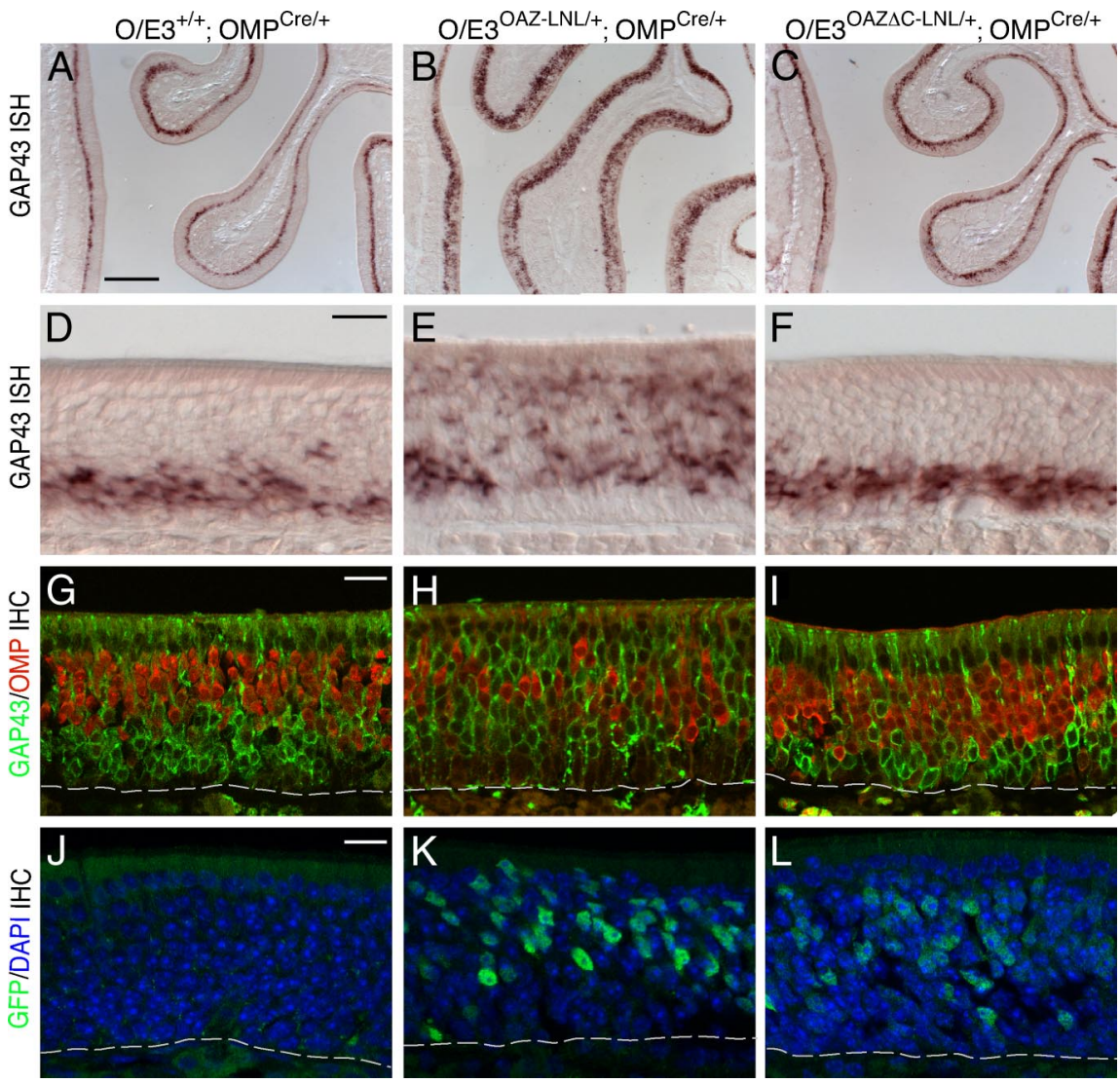

Figure 3. $0 / E$ defines and maintains a mature phenotype in MOE. $\boldsymbol{A}-\boldsymbol{F}, \mathrm{GAP} 43$ in situ hybridization after OMP-Cre recombination; the immature cells were confined to the basal layer in $0 / E 3^{0 A Z \Delta C-L N L /+}$ mice $(\boldsymbol{C}, \boldsymbol{F})$, similar to the wild-type background $(\boldsymbol{A}, \boldsymbol{D})$. This contrasts with the pattern of immature cells in the apical MOE of $0 / \mathrm{E}{ }^{\mathrm{OAZ}-\mathrm{LNL} /+}$ mice $(\boldsymbol{B}, \boldsymbol{E}) . \mathbf{G}-\mathbf{I}, 0 \mathrm{MP} / \mathrm{GAP43}$ double staining reveals that mature and immature cells were expressed in discrete apical and basal zones in $0 / \mathrm{E}^{\mathrm{OAZ} \triangle \mathrm{C}-\mathrm{LNL} /+} ; 0 \mathrm{MP} \mathrm{Cre} /+$ mice $(\boldsymbol{I})$ and $0 \mathrm{MP} \mathrm{Cre}^{++}$mice $(\boldsymbol{G})$. The mature cell region is replaced by immature cells in $0 / \mathrm{E}^{\mathrm{OAZ}-\mathrm{LNL} /+} ; 0 \mathrm{MP} \mathrm{Cre}^{++}$mice $(\boldsymbol{H})$. $\boldsymbol{J}-\boldsymbol{L}$, Nuclear YFP expression after $0 \mathrm{MP}$ recombina-

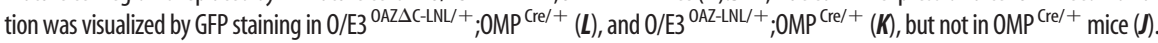
Scale bars: $\boldsymbol{A}-\mathbf{C}, 200 \mu \mathrm{m} ; \boldsymbol{D}-\boldsymbol{L}, 20 \mu \mathrm{m}$. All mice were examined at $\mathrm{P} 24$.

verge into glomeruli shortly after crossing the cribiform plate, but they appeared largely normal (Fig. 4G,H;n=7). The number of OSNs expressing each reporter appeared reduced in whole-mount preparations of $\mathrm{O} / \mathrm{E} 3^{\mathrm{OAZAC}}$ mice (Fig. $4 E-H ; n=7$ ) and upon quantification in tissue sections was reduced by one-half (Fig. 4I,J; $n=3$ pairs for each reporters). Although the OSNs were somewhat fewer in number, the signal intensity and morphology of the labeled neurons were normal (Fig. 4G,H, inset), consistent with normal terminal differentiation. The reporter-labeled OSNs in $\mathrm{O} / \mathrm{E} 3{ }^{\mathrm{OAZ}}$ mice background exhibited a severe targeting defect in the $\mathrm{OB}$ and scattered cells in the MOE with weak staining, short dendrites, and no obvious axon extensions, suggesting they were all arrested in premature stage (Cheng and Reed, 2007).

\section{Contribution of BMP signals in adult MOE}

BMP signaling, the other activity associated with OAZ protein, is a negative regulator for neurogenesis in MOE. Among the BMP ligands, BMP4 was expressed the most abundantly and was documented as an important inhibitor of neurogenesis (Shou et al., 1999). We examined the expression status of BMP2, 4, 6 in adult MOE by ISH. BMP4 mRNA was detected throughout the epithelium and somewhat more abundant in the basal layer (Fig. 5B). BMP6 was present at low levels, while BMP2 was undetectable (Fig. $5 A, C)$. These observations indicate that BMPs are expressed in adult MOE and could participate in OSN differentiation and maturation.
To examine the collective contributions of BMP signaling in the adult MOE, we expressed human Follistatin (hFST), a BMP receptor antagonist that has potent cross-species activity, broadly and at high levels within the MOE and investigated alterations in gene transcription and cellular differentiation. hFST (Kistner et al., 1996) was expressed in sustentacular cells as a doxycycline-inducible system under the control of the cell-specific cyp2g1-rtTA (Lane et al., 2010) and TRE-hFST. After one month of doxycycline induction, hFST increased 700-fold in wt and OAZ $\Delta$ C genetic background compared with control mice lacking one or both of the expression constructs ( $n=3$ for each genotype) (Fig. $5 D$ ) and transcription and protein expression was readily detectable by ISH and immunofluorescence (Fig. $5 E-L$ ). An overall uniform and patchy apical localization was readily detected throughout the MOE in induced mice (Fig. $5 F, H, J, L$ ) but was absent in uninduced animals (Fig. 5E, G, I,K).

We next determined whether antagonizing BMP signals leads to changes in expression of immature/mature markers. Stem cells initiate the neuronal lineage that is Mash1 dependent and proceeds through Ngn1 and NeuroD1-expressing transient amplifying progenitors (Gordon et al., 1995; Cau et al., 1997; Packard et al., 2011). Although we observed the expected alterations in expression associated with persistent OAZ or OAZ $\triangle \mathrm{C}$ expression, no reproducible changes associated with robust maintained FST are detected (Fig. 5M). This conclusion is also supported by immunofluorescence for GAP43 (Fig. 5I-L). Finally, we investigated the expression level of the stage-representative neuronal markers, Mash1, Ngn1, and NeuroD1. By Q-PCR, high levels of FST produced no significant differences in expression between the induced and uninduced groups, or in OAZ $\triangle \mathrm{C}$-containing and wt mice (Fig. $5 N$ ). Based on these experiments, BMP signals appear to contribute little, if at all, to the dynamics of cell differentiation and gene expression in normal adult MOE.

\section{Discussion}

\section{The importance of $\mathrm{O} / \mathrm{E}$ transcription factors in olfactory} differentiation and maintenance

Temporal expression of transcriptional factors promotes OSN differentiation and maturation. $\mathrm{O} / \mathrm{E}$ transcription factors participate at critical developmental stages in multiple cell lineages (Lin and Grosschedl, 1995; Wang et al., 1997; Corradi et al., 2003; Hesslein et al., 2009; Jin et al., 2010). The embryonic and neonatal lethality associated with functional knock-out of some $\mathrm{O} / \mathrm{E}$ genes and the considerable redundancy of expression in other tissues complicated analysis of O/E function (Garel et al., 1999; Wang et al., 2004). This is especially problematic in olfactory tissue where all four genes are expressed in a similar pattern (Wang et al., 2004). Although lethality could potentially be overcome by conditional knock-outs using tissue- or cell-specific promoters, elimination of all four family members is impractical. The persistent expression of the OAZ pro- 
tein that, as one of its activities, disrupted O/E activity (Cheng and Reed, 2007), suggested an important role for $\mathrm{O} / \mathrm{E}$ proteins in establishment of normal olfactory epithelium. However, additional activities associated with the OAZ protein could also have contributed to the observed phenotype. Our observations here strongly support a model in which the presence of functional $\mathrm{O} / \mathrm{E}$ factors is essential to drive differentiation of OSNs. Specifically, comparison of the $\mathrm{O} / \mathrm{E} 3^{\mathrm{OAZ}}$ and $\mathrm{O} / \mathrm{E} 3^{\mathrm{OAZ} \Delta \mathrm{C}}$ mouse lines that differ by a single nucleotide at the genomic level and loss of a single protein interaction domain reveals dramatic phenotypic differences. The arrest of cells at an immature state observed with OAZ protein competent for $\mathrm{O} / \mathrm{E}$ interaction but not a variant that lacks this activity $(\mathrm{OAZ} \Delta \mathrm{C})$ is consistent with a dominant loss of function for all $\mathrm{O} / \mathrm{E}$ family members during OSN development. The arrested cells fail to express $\mathrm{O} / \mathrm{E}$ target genes, while cells containing the OAZ $\Delta \mathrm{C}$ allele express these genes similar to wt cells. Importantly, in both of these OAZ proteins, the domains associated with BMP signaling pathways remain intact and their role, if any, should be unaltered in MOE.

Introduction of $\mathrm{OAZ} / \Delta \mathrm{C}$ later in differentiation suggests that $\mathrm{O} / \mathrm{E}$ function is important to maintain the mature state, not just initiate the differentiation program. The reactivation of $\mathrm{GAP}_{4} 3^{+}$cells when OAZ is introduced in mature populations indicates that OAZ, but not OAZ $\Delta \mathrm{C}$, is sufficient to abolish $\mathrm{O} / \mathrm{E}$ transcriptional target expression. In contrast, the presence of normal $\mathrm{OMP}^{+}$cells after introduction of OAZ $\Delta \mathrm{C}$ to mature cells suggests that its retained activities are insufficient to revert OSNs to an immature state and infer an important role for $\mathrm{O} / \mathrm{E}$ proteins in actively maintaining the mature phenotype. Furthermore, OAZ $\Delta \mathrm{C}$, but not OAZ, potentially allows both $\mathrm{O} / \mathrm{E}$ and BMP pathways to participate through the OSN differentiation process. Our observations suggest that, in OSNs, O/E activation plays a dominant role compared with other processes, like BMP signaling, that might be expected to exert an opposing effect in development (Shou et al., 2000; Gokoffski et al., 2011).

\section{Long-term interference with BMP signaling has little impact on adult OSN neurogenesis}

BMP signaling plays a well described role during development in several neuronal systems. In the olfactory epithelium, analysis of FST and GDF11 knock-outs suggested a modulatory role for this pathway that was further characterized in vitro (Shou et al., 2000; Wu et al., 2003). FST regulate propor-
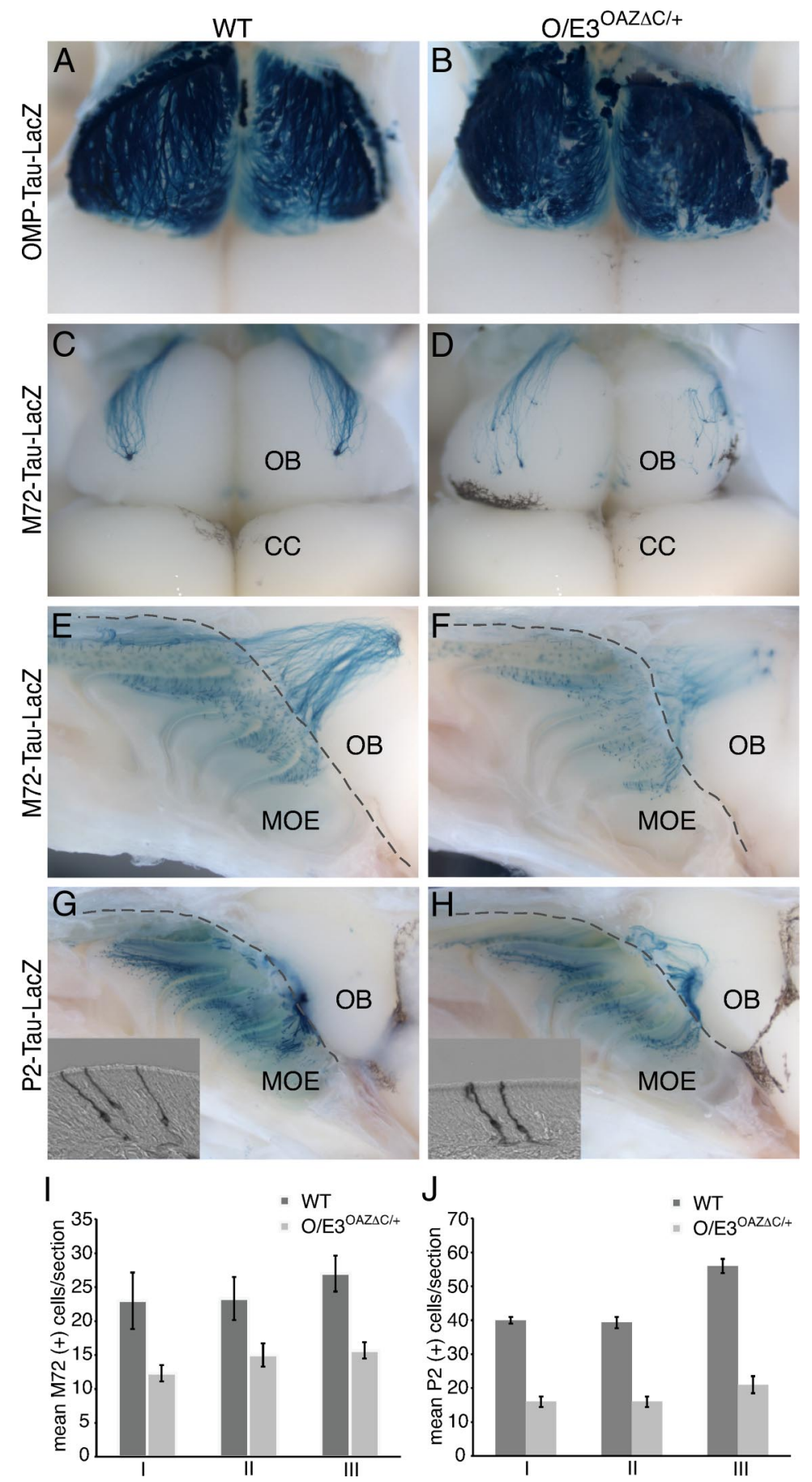

Figure 4. Modest glomeruli projection defects and OR-positive cells in $0 / E 3^{0 A Z \Delta C /+}$ mice. $A, B$, Whole-mount $\mathrm{X}$-gal staining of OMP-Tau-lacZ repotrter. Glomeruli distribution is largely normal in dorsal $\mathrm{OB}$ of $0 / \mathrm{E}^{\mathrm{OAZ} \Delta \mathrm{C} /+} ; \mathrm{OMP}$ Tau-LacZ/+ mice. Age, P18. C-F, Whole-mount X-gal staining of M72-TauLacZ reporter in dorsal view $(\boldsymbol{C}, \boldsymbol{D})$ and medial view $(\boldsymbol{E}, \boldsymbol{F})$. $\mathrm{OR}^{+}$OSN number was reduced in $0 / \mathrm{E}^{\mathrm{OAZ} \Delta \mathrm{C} /+} ; \mathrm{M} 72^{\text {Tau-LacZ/+ }}$ mice. The axons of M72-positive OSNs in $0 / \mathrm{E} 3^{\mathrm{OAZ} \Delta \mathrm{C} /+}$; $M 72^{\text {Tau-LacZ/+ }}$ follow the same route on dorsal and medial OB, but innervate into ectopic glomeruli. $n=7$ for $0 / \mathrm{E}^{\mathrm{OAZ} \Delta \mathrm{C} /+}{ }^{\prime}$; M72 ${ }^{\text {Tau-LacZ/+ }}$ mice. Age, P18. WT, The respective reporter lines that lack the $0 A Z \Delta$ C allele. $\boldsymbol{G}, \boldsymbol{H}$, Whole-mount X-gal staining of P2-Tau-LacZ reporter in medial view. Modest reduction in P2-positive OSNs were present in $0 / \mathrm{E}{ }^{\mathrm{OAZ} \triangle \mathrm{C} /+}$; $\mathrm{P}^{\text {Tau-LacZ/+ }}$ mice. Inset, X-gal staining for coronal section showed normal morphology and intensity for P2-positive cells in $0 / \mathrm{E}{ }^{\mathrm{OAZ} \Delta \mathrm{C} /+} ; \mathrm{P} 22^{\text {Tau-LacZ/+ }}$ mice. $n=7$ for $0 / \mathrm{E}^{\mathrm{OAZ} \Delta \mathrm{C} /+} ; \mathrm{P} 2^{\text {Tau-LacZ/+ }}$ mice. Age, P18. I, J, OR-positive OSNs, quantified in coronal sections at different locations (I, II, and III) of $0 / E 3{ }^{\mathrm{OAZ} \Delta \mathrm{C} /+}$ mice, exhibit a $\sim 50 \%$ reduction for the $\mathrm{M} 72$ and $\mathrm{P} 2$ reporter lines. Error bars indicate SEM. $p<0.001$ in each case. $n=3$ matched pairs for each genotype. Age, P18. The dashed line marks cribriform plate dividing $\mathrm{OB}$ and $\mathrm{MOE}$. $\mathrm{OB}$, Olfactory bulb; $\mathrm{CC}$, cerebral cortex; $\mathrm{MOE}$, main olfactory epithelium. 

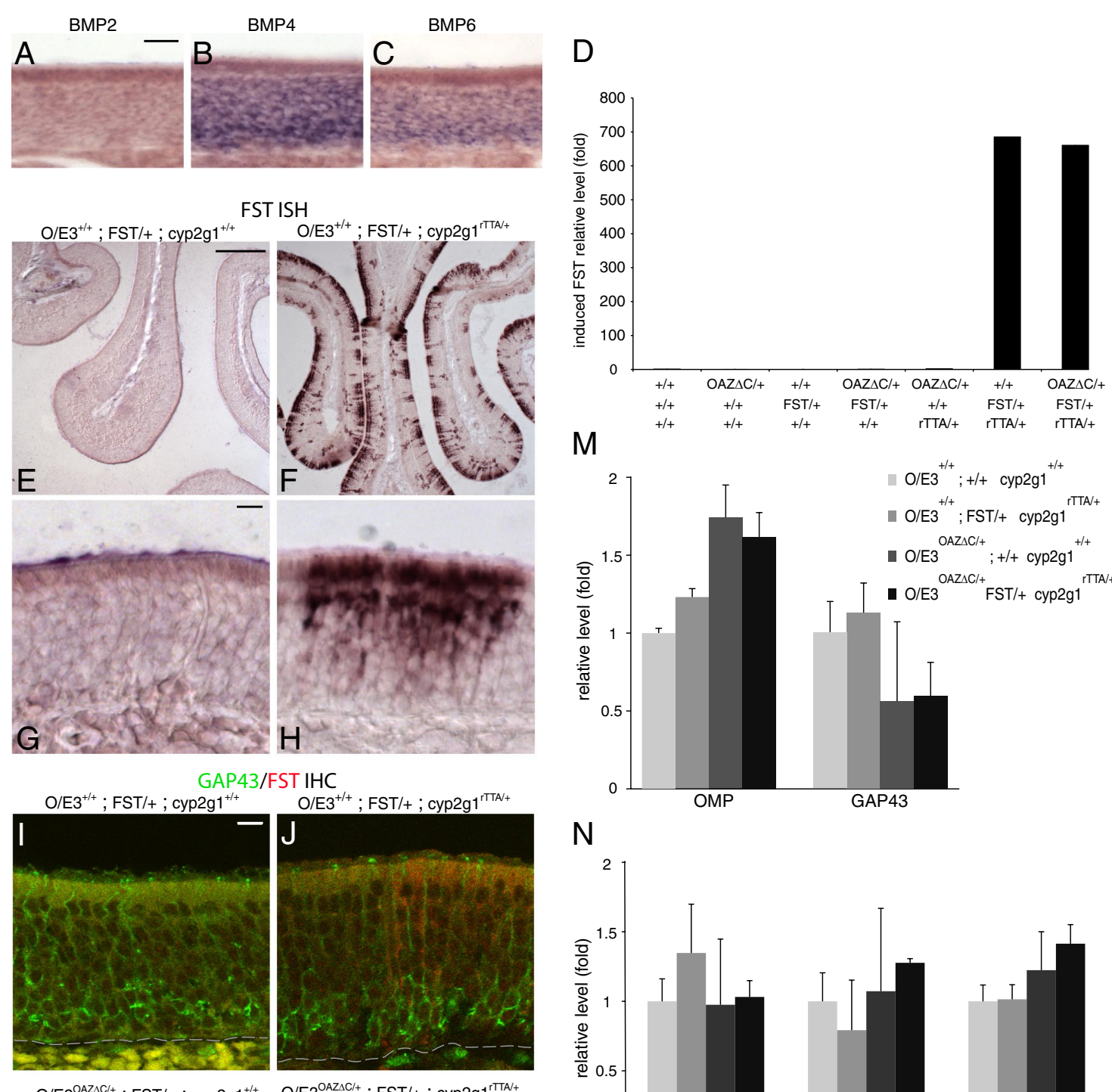

$\mathrm{O} / \mathrm{E3}^{\mathrm{OAZ} \triangle \mathrm{C} /+} ; \mathrm{FST} /+;{\text { cyp} 2 \mathrm{~g} 1^{+/+}}^{+/ 2}$
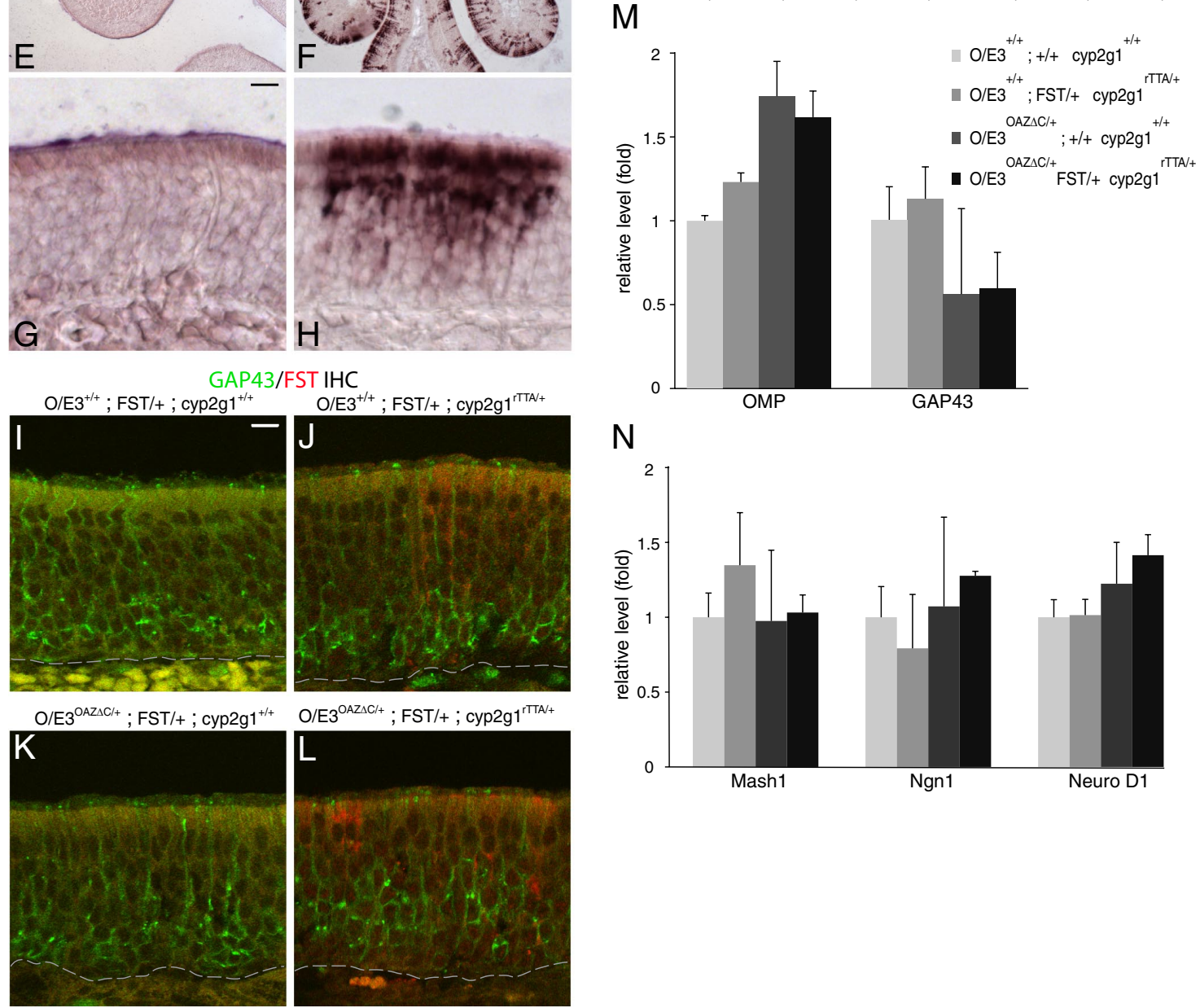

$\mathrm{N}$

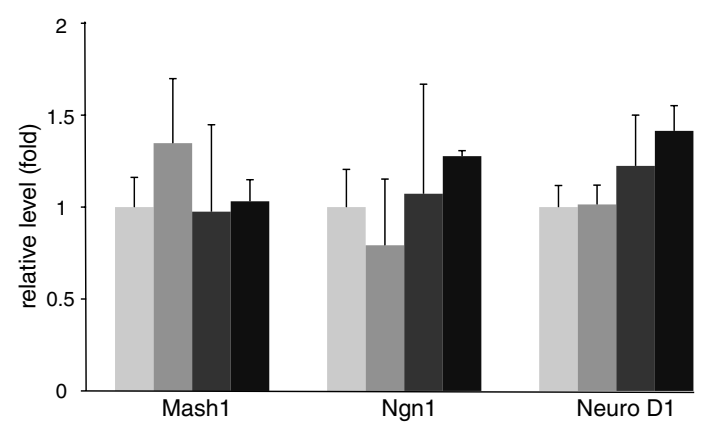

Figure 5. Expression of a BMP antagonist in MOE. A-C, In situ hybridization reveals BMP4 as an abundant BMP in MOE. Scale bar, $10 \mu \mathrm{m}$. D, Quantification of hFST expression by Q-PCR in MOE tissue after 1 month induction. The relative levels were determined by comparing normalized Ct of mice carrying only the inducible FST transgene. $n=3$ for each genotype. Error bars indicate SEM. $\boldsymbol{E}-\boldsymbol{H}$, FST in situ hybridization displayed robust and broad but patchy expression in induced mice, but no expression in FST-alone mice. Scale bars: $\boldsymbol{E}, \boldsymbol{F}, 200 \mu \mathrm{m} ; \boldsymbol{G}, \boldsymbol{H}, 10 \mu \mathrm{m}$. I-L, FST/GAP43 double staining revealed no detectable alterations in immature markers after 1 month of FST induction in wild-type and OAZ $\Delta$ C background. Scale bar, $10 \mu \mathrm{m}$. $\boldsymbol{M}, \boldsymbol{N}$, Quantification of cell differentiation markers ( $\boldsymbol{M}$ ) and gene transcription $(\boldsymbol{N})$ by Q-PCR following 1 month of FST induction. No significant changes were detected for these markers in any of the genotypes. $n=3$ for each genotype. Error bars indicate SEM.

tions of cell lineages by targeting stem/progenitor cells and immediate neuronal precursors through GDF11 and Activin at embryonic stage (Gokoffski et al., 2011). Despite robust FST induction in adult MOE, we did not observe significant perturbations in neuronal lineage populations or in cell type-specific gene expression. The ability of susentacular cells to secrete other extracellular proteins in a genetic system similar to the one described here (Lane et al., 2010) and the robust developmental response in mice carrying the same hFST gene (Lee, 2007), suggests that the hFST is secreted as a biologically active and functional protein. Our studies initiated FST induction in normal intact MOE at a time when initial establishment of the epithelium was largely complete. Our data indicate antagonizing BMP alone is not sufficient to alter neurogenesis after the MOE is established. Alternatively, chronic interfering BMP signals achieves a dynamic balance that maintains a relative constant proportion in each cell population (Lander et al., 2009).

BMP signaling is one of the key cues in olfactory placode specification and MOE patterning at early developmental stages (Sjödal et 
al., 2007; Maier et al., 2010). However, the effects of interfering with BMP signaling during neuronal regeneration after injury or during embryonic development remains largely unexplored. In our studies, the postnatal expression of $c y p 2 g 1$ gene used to direct FST expression (Zhuo et al., 2001) precludes an analysis of the consequences of early induction of FST in the MOE. However, this system should be amenable to future studies in which the adult epithelium is damaged and allowed to regenerate.

\section{$\mathrm{O} / \mathrm{E}$ function and OR gene choice}

In addition to regulating cell differentiation, $\mathrm{O} / \mathrm{E}$ proteins also likely participate in OR selection (Mombaerts, 2004; Vassalli et al., 2011). The molecular mechanisms regulating OR gene choice are complicated and remain elusive. The mechanisms include feedback inhibition signal and alterations in epigenetic signatures (Serizawa et al., 2003; Lewcock and Reed, 2004; Magklara et al., 2011). OR selection occurs at a specific time window that is developmentally regulated. The accumulated aberrant $\mathrm{OR}^{+}$cells in $\mathrm{O} / \mathrm{E} 3{ }^{\mathrm{OAZ}}$ mice were arrested in the immature stage as a consequence of suppressing $\mathrm{O} / \mathrm{E}$ activity. As a result, multiple or preferentially expressed ORs may persist in the same OSN, thus perturbing the final OR choice. In contrast, the relatively normal selection of the P2 and M72 ORs in O/E3 ${ }^{\mathrm{OAZ} \Delta \mathrm{C}}$ mice reflects successful execution of the choice process in terminally differentiated OSNs. The O/E proteins have putative binding sites in OR promoters and may directly participate in OR selection; they may alternatively or additionally define the differentiation state at which OR choice occurs.

\section{References}

Cau E, Gradwohl G, Fode C, Guillemot F (1997) Mash1 activates a cascade of bHLH regulators in olfactory neuron progenitors. Development 124 : 1611-1621. Medline

Cheng LE, Reed RR (2007) Zfp423/OAZ participates in a developmental switch during olfactory neurogenesis. Neuron 54:547-557. CrossRef Medline

Corradi A, Croci L, Broccoli V, Zecchini S, Previtali S, Wurst W, Amadio S, Maggi R, Quattrini A, Consalez GG (2003) Hypogonadotropic hypogonadism and peripheral neuropathy in Ebf2-null mice. Development 130: 401-410. CrossRef Medline

Garel S, Marín F, Grosschedl R, Charnay P (1999) Ebfl controls early cell differentiation in the embryonic striatum. Development 126:5285-5294. Medline

Gokoffski KK, Wu HH, Beites CL, Kim J, Kim EJ, Matzuk MM, Johnson JE, Lander AD, Calof AL (2011) Activin and GDF11 collaborate in feedback control of neuroepithelial stem cell proliferation and fate. Development 138:4131-4142. CrossRef Medline

Gordon MK, Mumm JS, Davis RA, Holcomb JD, Calof AL (1995) Dynamics of MASH1 expression in vitro and in vivo suggest a non-stem cell site of MASH1 action in the olfactory receptor neuron lineage. Mol Cell Neurosci 6:363-379. CrossRef Medline

Graziadei GA, Graziadei PP (1979) Neurogenesis and neuron regeneration in the olfactory system of mammals. II. Degeneration and reconstitution of the olfactory sensory neurons after axotomy. J Neurocytol 8:197-213. CrossRef Medline

Hagman J, Belanger C, Travis A, Turck CW, Grosschedl R (1993) Cloning and functional characterization of early B-cell factor, a regulator of lymphocyte-specific gene expression. Genes Dev 7:760-773. CrossRef Medline

Hata A, Seoane J, Lagna G, Montalvo E, Hemmati-Brivanlou A, Massagué J (2000) OAZ uses distinct DNA- and protein-binding zinc fingers in separate BMP-Smad and Olf signaling pathways. Cell 100:229-240. CrossRef Medline

Hesslein DG, Fretz JA, Xi Y, Nelson T, Zhou S, Lorenzo JA, Schatz DG, Horowitz MC (2009) Ebf1-dependent control of the osteoblast and adipocyte lineages. Bone 44:537-546. CrossRef Medline

Jin K, Jiang H, Mo Z, Xiang M (2010) Early B-cell factors are required for specifying multiple retinal cell types and subtypes from postmitotic precursors. J Neurosci 30:11902-11916. CrossRef Medline
Kistner A, Gossen M, Zimmermann F, Jerecic J, Ullmer C, Lübbert H, Bujard H (1996) Doxycycline-mediated quantitative and tissue-specific control of gene expression in transgenic mice. Proc Natl Acad Sci U S A 93:1093310938. CrossRef Medline

Lander AD, Gokoffski KK, Wan FY, Nie Q, Calof AL (2009) Cell lineages and the logic of proliferative control. PLoS Biol 7:e15. CrossRef Medline

Lane AP, Turner J, May L, Reed R (2010) A genetic model of chronic rhinosinusitis-associated olfactory inflammation reveals reversible functional impairment and dramatic neuroepithelial reorganization. J Neurosci 30:2324-2329. CrossRef Medline

Lee SJ (2007) Quadrupling muscle mass in mice by targeting TGF-beta signaling pathways. PLoS One 2:e789. CrossRef Medline

Leung CT, Coulombe PA, Reed RR (2007) Contribution of olfactory neural stem cells to tissue maintenance and regeneration. Nat Neurosci 10:720-726. CrossRef Medline

Lewcock JW, Reed RR (2004) A feedback mechanism regulates monoallelic odorant receptor expression. Proc Natl Acad Sci U S A 101:1069-1074. CrossRef Medline

Lin H, Grosschedl R (1995) Failure of B-cell differentiation in mice lacking the transcription factor EBF. Nature 376:263-267. CrossRef Medline

Magklara A, Yen A, Colquitt BM, Clowney EJ, Allen W, MarkenscoffPapadimitriou E, Evans ZA, Kheradpour P, Mountoufaris G, Carey C, Barnea G, Kellis M, Lomvardas S (2011) An epigenetic signature for monoallelic olfactory receptor expression. Cell 145:555-570. CrossRef Medline

Maier E, von Hofsten J, Nord H, Fernandes M, Paek H, Hébert JM, Gunhaga L (2010) Opposing Fgf and Bmp activities regulate the specification of olfactory sensory and respiratory epithelial cell fates. Development 137: 1601-1611. CrossRef Medline

Mombaerts P (2004) Odorant receptor gene choice in olfactory sensory neurons: the one receptor-one neuron hypothesis revisited. Curr Opin Neurobiol 14:31-36. CrossRef Medline

Mombaerts P, Wang F, Dulac C, Chao SK, Nemes A, Mendelsohn M, Edmondson J, Axel R (1996) Visualizing an olfactory sensory map. Cell 87:675-686. CrossRef Medline

Packard A, Giel-Moloney M, Leiter A, Schwob JE (2011) Progenitor cell capacity of NeuroD1-expressing globose basal cells in the mouse olfactory epithelium. J Comp Neurol 519:3580-3596. CrossRef Medline

Schwob JE (2002) Neural regeneration and the peripheral olfactory system. Anat Rec 269:33-49. CrossRef Medline

Schwob JE, Huard JM, Luskin MB, Youngentob SL (1994) Retroviral lineage studies of the rat olfactory epithelium. Chem Senses 19:671-682. CrossRef Medline

Serizawa S, Miyamichi K, Nakatani H, Suzuki M, Saito M, Yoshihara Y, Sakano H (2003) Negative feedback regulation ensures the one receptor-one olfactory neuron rule in mouse. Science 302:2088-2094. CrossRef Medline

Shou J, Rim PC, Calof AL (1999) BMPs inhibit neurogenesis by a mechanism involving degradation of a transcription factor. Nat Neurosci 2:339-345. CrossRef Medline

Shou J, Murray RC, Rim PC, Calof AL (2000) Opposing effects of bone morphogenetic proteins on neuron production and survival in the olfactory receptor neuron lineage. Development 127:5403-5413. Medline

Sjödal M, Edlund T, Gunhaga L (2007) Time of exposure to BMP signals plays a key role in the specification of the olfactory and lens placodes ex vivo. Dev Cell 13:141-149. CrossRef Medline

Tsai RY, Reed RR (1997a) Cloning and functional characterization of Roaz, a zinc finger protein that interacts with $\mathrm{O} / \mathrm{E}-1$ to regulate gene expression: implications for olfactory neuronal development. J Neurosci 17:4159-4169. Medline

Tsai RY, Reed RR (1997b) Using a eukaryotic GST fusion vector for proteins difficult to express in E. coli. Biotechniques 23:794-796, 798, 800.

Tsai RY, Reed RR (1998) Identification of DNA recognition sequences and protein interaction domains of the multiple- $\mathrm{Zn}$-finger protein Roaz. Mol Cell Biol 18:6447-6456. Medline

Vassalli A, Feinstein P, Mombaerts P (2011) Homeodomain binding motifs modulate the probability of odorant receptor gene choice in transgenic mice. Mol Cell Neurosci 46:381-396. CrossRef Medline

Verhaagen J, Oestreicher AB, Grillo M, Khew-Goodall YS, Gispen WH, Margolis FL (1990) Neuroplasticity in the olfactory system: differential effects of central and peripheral lesions of the primary olfactory pathway on 
the expression of B-50/GAP43 and the olfactory marker protein. J Neurosci Res 26:31-44. CrossRef Medline

Wang MM, Reed RR (1993) Molecular cloning of the olfactory neuronal transcription factor Olf-1 by genetic selection in yeast. Nature 364:121-126. CrossRef Medline

Wang SS, Tsai RY, Reed RR (1997) The characterization of the Olf-1/EBFlike HLH transcription factor family: implications in olfactory gene regulation and neuronal development. J Neurosci 17:4149-4158. Medline

Wang SS, Lewcock JW, Feinstein P, Mombaerts P, Reed RR (2004) Genetic disruptions of $\mathrm{O} / \mathrm{E} 2$ and $\mathrm{O} / \mathrm{E} 3$ genes reveal involvement in olfactory re- ceptor neuron projection. Development 131:1377-1388. CrossRef Medline

Wu HH, Ivkovic S, Murray RC, Jaramillo S, Lyons KM, Johnson JE, Calof AL (2003) Autoregulation of neurogenesis by GDF11. Neuron 37:197-207. CrossRef Medline

Zhuo X, Schwob JE, Swiatek PJ, Ding X (2001) Mouse Cyp2g1 gene: promoter structure and tissue-specific expression of a Cyp2g1-LacZ fusion gene in transgenic mice. Arch Biochem Biophys 391:127-136. CrossRef Medline 